\title{
2006-1548: A THIRD YEAR REVIEW OF THE FACULTY DEVELOPMENT PROGRAM AT MISSISSIPPI STATE UNIVERSITY
}

\section{Donna Reese, Mississippi State University}

Dr. Donna Reese is Associate Dean for Academics and Administration in the James Worth Bagley College of Engineering at Mississippi State University

\section{Kirk Schulz, Mississippi State University}

Dr. Kirk Schulz is Dean of Engineering in the James Worth Bagley College of Engineering at Mississippi State University

\section{Noel Schulz, Mississippi State University}

Dr. Noel Schulz is an Associate Professor and holder of the TVA Professorship in Power Systems in the Department of Electrical and Computer Engineering at Mississippi State University

\section{Roger King, Mississippi State University}

Dr. Roger King is Associate Dean for Research and Graduate Studies in the James Worth Bagley College of Engineering at Mississippi State University 


\section{A Third Year Review of the Faculty Development Program at Mississippi State University}

\section{Introduction}

Over the past three years, we have replaced over $25 \%$ of the faculty members within the Bagley College of Engineering at Mississippi State University due to retirements or departure to other universities. Many of the new faculty hires are at the Assistant Professor level, with little or no academic experience. In an effort to assist these faculty members in successfully starting their academic careers, the Bagley College of Engineering implemented a comprehensive faculty development program that assists new faculty members in balancing teaching, scholarship, and service responsibilities $[1,2]$. This program is now in its third year, and this paper will report on the significant impact that this program has had on new faculty members in regards to teaching effectiveness, effective national service, and research productivity.

\section{Current Faculty Development Program}

The faculty development program at Mississippi State falls into three distinct phases: programs for first-year faculty members, programs for untenured faculty members, and programs for all faculty members regardless of rank and tenure status. Some details on each of these three interrelated aspects of the faculty development program are described below. Details on the current program can be found on the Bagley College of Engineering website at:

http://www.engr.msstate.edu/faculty_staff/faculty_development/index.php.

The faculty development program is administered out of the Dean of Engineering office, with shared responsibilities between the Dean of Engineering, the Associate Dean for Academics and Administration, and the Associate Dean for Research and Graduate Studies. Each year, the Deans will meet to discuss the faculty development program, including suggested topics, key speakers, and who to invite as speakers/workshop coordinators.

First-Year Faculty Members

All first year faculty members at Mississippi State University attend university level orientation sessions that include presentations made by the President, Provost, Vice President for research and other senior administration officers. Mississippi State also organizes a bus tour which takes the new faculty members around Mississippi to see various industries in the state, meet different constituent groups who interact with the university, and in general to allow the new faculty members to interact together on a social basis. Immediately prior to this event, the Bagley College of Engineering hosts a lunch for new faculty members to introduce them to the various Deans and to allow them to meet the other new faculty members. 
During the first two weeks of class, we hold several key events, including a welcome reception at the Dean's house, a reception at a local restaurant with first and second year faculty members, and lunch with the new faculty members and their mentors.

Following the start of the semester, new faculty members have one activity per month that is expressly geared towards their needs as new faculty members. These include opportunities to meet with Office of Research Staff members, meetings with the Dean's office staff and learning their various responsibilities, and career tips from senior administrators. A summary of these activities is listed in Table 1.

\begin{tabular}{||l|l||}
\hline MONTH & EVENT \\
\hline August & New Faculty Lunch \\
\hline August & New Faculty Appetizers at Deans House \\
\hline August & New Faculty/Second Year Faculty Social \\
\hline August & New Faculty meet with Mentor Group \\
\hline September & New Faculty - Open Forum \\
\hline October & Meet Sponsored Programs \\
\hline November & Meet Dean's Office Staff \\
\hline December & $\begin{array}{l}\text { Tips for Getting Career Started - VP } \\
\text { Research }\end{array}$ \\
\hline January & Panel - Effective Service/Outreach \\
\hline February & Preparing to Visit a Research Sponsor \\
\hline March & Trip to National Science Foundation \\
\hline April & NSF CAREER Award Development Panel \\
\hline May & End of the Year Activity and Assessment \\
\hline \hline
\end{tabular}

Table 1: Faculty Development Activities for New Faculty Members

One of the key aspects of the faculty development program is assignment of faculty mentors for each new faculty member. Each Department Head is asked to nominate a senior faculty member to serve as a mentor for each untenured faculty member. The Deans meet with the mentor group prior to our new faculty - mentor lunch, and discuss tips for effective peer mentoring. Mentors are provided with key resource materials on effective mentoring, and are asked to meet with their mentee on a monthly basis.

One of the highlights for the year is the visit to the National Science Foundation (NSF). Several group visits are arranged where the entire group of new faculty members will meet with the appropriate Division Director, and individual faculty members will have appointments with their own program managers. The faculty members are strongly encouraged to volunteer as proposal reviewers, giving them experience seeing the proposal process from another side.

One of the challenges with hiring so many new faculty members is that it can be challenging for department heads, deans office staff, research center directors and the upper administration to remember the faces and expertise of the new faculty members. 
Each year, we compile a "new faculty" directory, with a picture of each new faculty member, as well as a short biographical sketch for each person. This is duplicated and widely circulated throughout the Bagley College of Engineering and the University.

\section{Untenured Faculty Members}

There are several events that are held each year for untenured faculty members. We hold a social event between the new faculty member and second-year faculty members to allow the new faculty members some idea of what to expect during the first year from other faculty members who were recently "in their shoes". Additionally, we invite the untenured faculty members to several other events including a description of the federal relations initiatives and how to participate, and a general seminar on career advice from a senior administrator. A summary of these activities is listed in Table 2.

\begin{tabular}{||l|l||}
\hline MONTH & EVENT \\
\hline August & Second Year Faculty/New Faculty Social \\
\hline September & Understanding Federal Relations at MSU \\
\hline November & $\begin{array}{l}\text { Tips for Getting Career Started - VP } \\
\text { Research }\end{array}$ \\
\hline April & NSF CAREER Award Development Panel \\
\hline
\end{tabular}

Table 2: Faculty Development Activities for Untenured Faculty Members

\section{All Faculty Members}

The College of Engineering also holds several events that are geared for an open faculty audience, regardless of rank, tenure status, or time at the university. We sponsor two "brown bag" lunches each semester with a focus on effective teaching. These seminars are led by faculty members who are among the most effective teaching faculty at Mississippi State. These lunches are done in a panel format, with two faculty members discussing a particular teaching topic, followed by open discussion with the audience. Additionally, at least one research related topic is also part of the faculty development program each semester, so that all faculty members have the opportunity to grow in their careers. A summary of these activities is listed in Table 3.

\begin{tabular}{||l|l||}
\hline MONTH & EVENT \\
\hline September & Brown Bag Lunch on Teaching and \\
& Learning - Using Technology Effectively \\
\hline September & Understanding Federal Relations at MSU \\
\hline November & Brown Bag Lunch on Teaching and \\
& Learning - Teaching Introductory Courses \\
\hline February & Brown Bag Lunch on Teaching and \\
& Learning - Teaching Senior Design \\
\hline April & Brown Bag Lunch on Teaching and \\
& Learning - Incorporating ABET \\
& Assessment into Engineering Courses \\
\hline
\end{tabular}




\section{Table 3: Faculty Development Activities for All Faculty Members}

\section{Program Impact}

The faculty development program has had a significant impact on Mississippi State University faculty members in starting their careers in several key areas, which are given below. By the end of this academic year, somewhere over 20 new faculty members will have passed through this program. While we are in the process of collecting quantitative assessment data on this program, we have observed several key impacts from a college administrative point of view, which may suggest the adoption of a similar type of program at other engineering schools.

The new faculty members develop a group of peers to socialize with across disciplinary boundaries. Many of the new faculty members will socialize off-hours, and often develop friendships outside of their department during their first couple of months on campus. This network also provides moral support during a very difficult adjustment period for many faculty members.

\section{A group visit to the National Science Foundation is a friendly way to introduce faculty members to the peer review process. Many of the new faculty members are asked to participate in an NSF panel following their visit, and gain a much better understanding of the peer and panel review process. Several of the faculty members have commented on the importance of this experience when developing their own proposals by having the opportunity to read both high quality and poor quality proposals.}

\section{Opportunities to meet and ask questions of high-level administrators are beneficial to the newer faculty members and the administrators. Many high-level university administrators have a broad range of research and teaching experience, but are often too busy or involved in meetings to meet and mentor individual faculty members. By having these key administrators meet with the new faculty members in a smaller, more intimate setting, it gives both the administrators and the new faculty members an opportunity to get to know each other well. Many of the presentations made by key administrators have been very effective.}

Any faculty development program must have opportunities for new faculty as well as more established faculty members. It is key to make sure to bring new ideas to senior faculty as well as junior faculty members. Additionally, as faculty members work progress in their careers, many will take on greater leadership roles, will teach more, and will lead large research teams. All of these require skills that may not be obtained during the first few years when initiating a research program as a junior faculty member.

\section{Summary}

The faculty development program at Mississippi State University is in its third year, and has had a significant impact on the faculty. A high quality faculty development program 
can easily be put in place that will have a significant impact in any institution using expertise available at any university for a very reasonable cost.

\section{Bibliography}

[1] Noel N. Schulz and Kirk H. Schulz, "Faculty Development - The Future of Engineering Education", Proceedings of the 2004 Annual ASEE Conference, Salt Lake City, Utah, Session 1475, 2004.

[2] Noel N. Schulz and Kirk H. Schulz, "Investing in Faculty - A Comprehensive Faculty Development Program", Proceedings of the 2005 ASEE Southeast Section Conference, Chattanooga, TN, 2005. 